Proc. Estonian Acad. Sci. Geol., 1995, 44, 3, 177-183

\title{
ON THE AGE OF THE METEORITE CRATERS AT KAALI (SAAREMAA ISLAND, ESTONIA)
}

\author{
Anto RAUKAS, Reet PIRRUS, Raivo RAJAMĀE, and Reet TIIRMAA
}

Eesti Teaduste Akadeemia Geoloogia Instituut (Institute of Geology, Estonian Academy of Sciences), Estonia pst. 7, EE-0100 Tallinn, Eesti (Estonia)

Received 22 February 1995, accepted 28 March 1995

Abstract. Various methods have been used to determine the age of the Kaali craters. Most of contemporary investigators believe the age of the craters to be some 4000 years. Studies of microtektites in the Piila mire close to Kaali have concluded that the craters were formed some 7500 years ago.

Key words: microtektites, meteorite craters, palynology, radiocarbon datings, chronostratigraphical markers, Estonia.

\section{INTRODUCTION}

The craters at Kaali have attracted scientists since the first half of the last century. Von Luce (1827) presented the first description of the Kaali main crater. In 1839, a foot-scale topographical map of Lake Kaali was compiled by Kruse (1842). Between 1827 and 1928, different hypotheses were advanced as to the origin of the Kaali craters: volcanic, eruption, karst subsidence, and salt or gypsum tectonics (Tiirmaa, 1994). In 1927, Reinwaldt $(1928,1933)$ established the meteoritic origin of the main crater. In 1937, he collected 30 fragments of meteoritic iron from satellite craters No. 2 and 5 (Reinwald, 1938). For a long time the Kaali craters were the only geologically established meteorite craters in Europe.

Various methods have been used to determine the age of the Kaali craters. Since neither deformed remnants from the explosion nor later sediments of marine origin had been found in the crater, Linstow (1919) estimated the age of the crater at about $4000-8000$ years. Basing on salt tectonics, Kraus et al. (1928) reached the conclusion that these craters should have been formed more than 12000 years ago.

Since no traces of marine erosion or accumulation had been found in the craters or their embankments, Reinwald (1937) considered the craters some $4000-5000$ years in age. In his first papers Aaloe (1958) expressed the same opinion, but a few years later he maintained that the age of the craters could not be more than 3000-4000 years (Аалоэ, 1963). The ${ }^{14} \mathrm{C}$ dating of charcoal discovered in 1961 , yielded an age of $2660 \pm 200$ years (Aaloe et al., 1963); the later dates $2530 \pm 130$ and $2920 \pm 240$ years allowed Aaloe to place the age of the craters at about $2800 \pm 100$ years (Aaloe et al., 1975). Taking into consideration archaeological evidence from the burning of Asva and Ridala strongholds, some investigators concluded that a meteorite could have fallen at Kaali before the turn of the 7 th and 8 th centuries B. C., about 2600 years ago (Aaloe et al., 1977). 


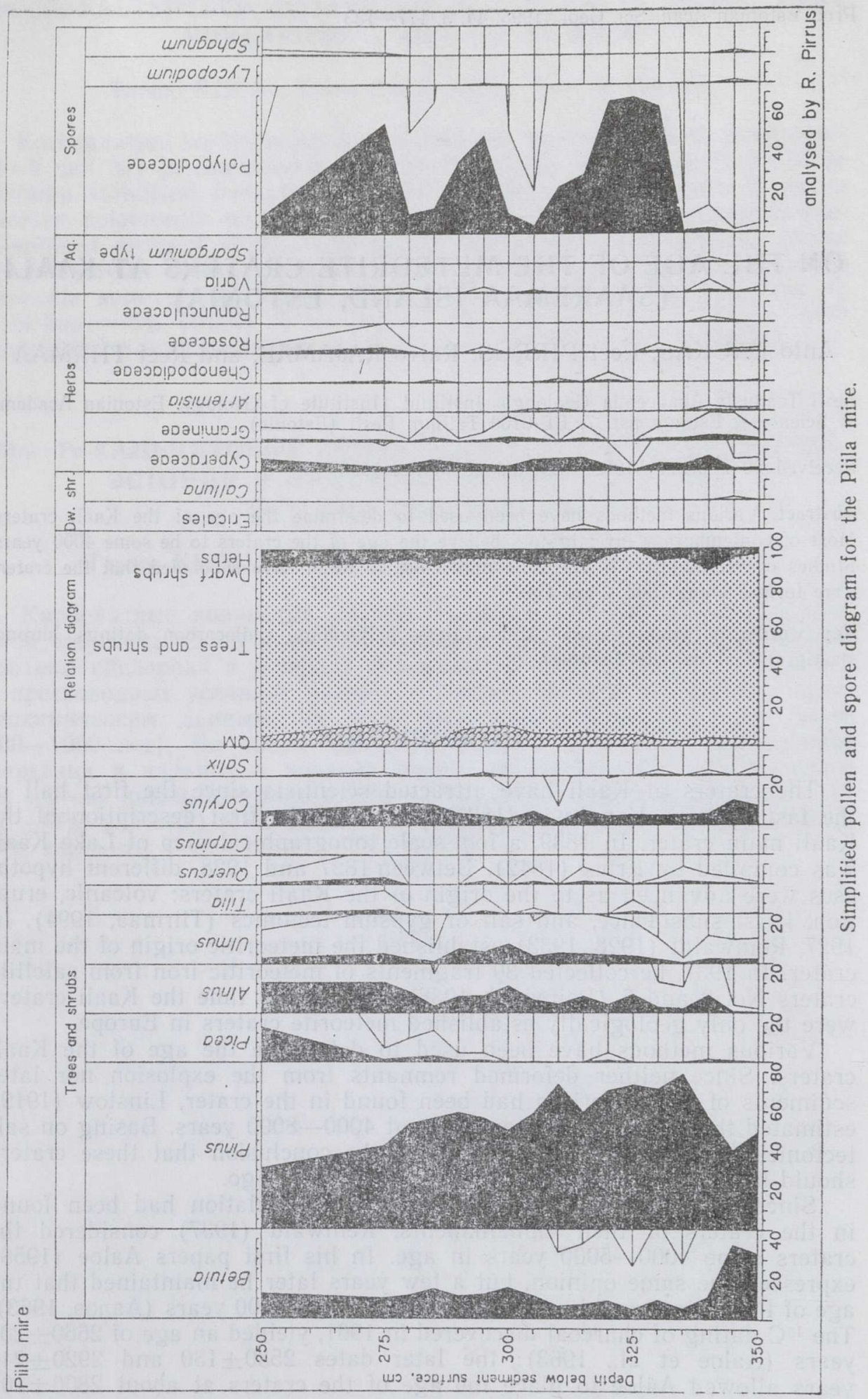


It is clear that the dated charcoal can be much younger than the craters themselves and, therefore, great hopes were placed on the drilling and dating of lake sediments in the main crater. The palynological analysis carried out by Kessel (1981), showed that the bottommost sediments are Subboreal, and the explosion of meteorite took place at least 3500 years ago. Later complex research and the simultaneous ${ }^{14} \mathrm{C}$ and palynological investigations initiated by Saarse, placed the craters' age at about 40003500 years (Saarse et al., 1990) or 4000 years B. P. (Saarse et al., 1991). In our opinion the study of bottom sediments of the craters enables one to establish only the minimal age of the craters but not the time when the meteorite actually fell to the Earth.

\section{WORK HYPOTHESIS}

The soil both in the Kaali craters and their surroundings contains a lot of pulverized meteoritic matter, including microtektites, formed from molten or vaporized silicate minerals during the explosion (Аалоэ \& Тийрmaa, 1981; Shymanovich et al., 1993). This provides a basis for the supposition that, most probably, extraterrestrial and explosion material would also occur at certain stratigraphical levels in the surrounding lakes and peat bogs, providing excellent stratigraphical markers for the correlation of marine and terrestrial sedimentary sequences and enabling the dating of the impact event in the most precise way.

To find the traces of the impact activity over the course of the Pleistocene epoch, we undertook to study the most complete sequences of Belarus (Shimanovich et al., 1995), however, failed to establish any clear concentration of extraterrestrial matter or microtektites. At the same time, a high concentration of microtektites was detected in the bottommost part of the Piila mire, about $10 \mathrm{~km}$ to the northwest from the Kaali craters. The age of the layer with microtektites was established by means of palynological and radiocarbon methods.

\section{SITE DESCRIPTION AND THE METHODS USED}

The Piila mire (1949 ha) in the Kaarma Commune on Saaremaa Island was formed as a result of paludification of a relic lake. In the mire, which is fed by ground water and precipitation, fen forest blends into a wooded mire, patches of cultivated land alternate with peat-milling sites. According to $M$. Orru (pers. comm.), of the total area under the peat deposit, 1420 ha are in the fen, and 529 ha in the high moor. In the fen the mean thickness of the peat layer is $1.4 \mathrm{~m}$, and it consists mainly of averagely decomposed $(35-43 \%)$ reed peat, the ash content of which is $2.1 \%$ and moisture $91 \%$. The 2.5 -metre-thick high moor peat deposits consist mostly of fuscum (decomposition degree $24 \%$, ash content $3.2 \%$, and moisture content $93.5 \%$ ).

In the studied dug hole, the peat layer was $3.40 \mathrm{~m}$ thick. The uppermost $2 \mathrm{~m}$ were represented by little decomposed sphagnum peat and the lowermost $1.4 \mathrm{~m}$ were reed peat with wood remnants. The bottom of the borehole was covered with bluish-grey lake clay which contained plant remains. Since we expected to find a microtektite layer in the 4000-5000-year-old bed, the samples for palynological analysis were taken from the topmost peat layer after every $25 \mathrm{~cm}$. Starting from a depth of $2 \mathrm{~m}$ the sampling interval was $5 \mathrm{~cm}$. Samples for ${ }^{14} \mathrm{C}$ analysis were taken from the bottommost part of the peat (at a depth of $335-340 \mathrm{~cm}$ ) with an aim of establishing the age of the sea regression and the start of paludification of the 
site area. One sample was taken at a depth of $225-250 \mathrm{~cm}$ to facilitate palynological interpretation. The samples of peat were burnt to ashes at $400^{\circ} \mathrm{C}$. After washing to remove the ash component, spherules were collected under a binocular microscope. The impact matter was studied by means of a scanning electron microscope BS 300 and microsond. A clear concentration of spherules was established at a depth of $3.00-3.10 \mathrm{~m}$, some particles occurred also at a depth of $3.10-3.25 \mathrm{~m}$. Samples from other depths were barren of meteoritic matter.

Both magnetite-silicate and silicate spherules were established with the prevalence of the latter. Mainly ellipsoidal or drop-like well-shaped globules occurred. They have smooth lustrous surfaces, sometimes with hollows indicating gas eruptions. Figures $1-8$ in the Plate present the data on the microtektites (impactites) most typical of the section. Figures $1-4$ show oval or drop-shaped light-beige to dark-brown, amorphous, opaque spherules with smooth surfaces of greasy lustre. The spherules are rich in cavities, sometimes they are hollow from inside (Plate, figs. 1, 2). The platelets of spherule pieces with the conchoidal fracture (Plate, figs. $3,4)$ display abundant hollows indicating gas eruptions. The positive tubercles on the planes consist mostly of magnetite crystals. Figures 5,6 depict aggregates, the rough many-coloured surfaces of which have an opal lustre, and figs. 7, 8 show spherical or oval rough-surfaced spherules. The spots of the surface which are crusted with ferric oxide (Plate, fig. 7) are reddish-brown. In fig. 6 one can see a drop-shaped nonbroken gasfilled vesicle, fig. 8 is hollow. Magnetite crystals occur on planes.

The research was initiated, material collected and the paper compiled by the first author. R. Tiirmaa treated the samples, collected and described the spherules. Palynological analyses were made by $R$. Pirrus and ${ }^{14} \mathrm{C}$ analyses by R. Rajamäe. U. Moldov and G. Baranov made the scanning electron photos and T. Kallaste microsond analysis.

\section{THE AGE OF MICROTEKTITES}

The age of microtektites in the peat layer was determined using both palynological and ${ }^{14} \mathrm{C}$ methods. As the covering sphagnum peat was barren of spherules, in the palynological diagram (Figure) only the reed peat layer is shown. As mentioned above, the sampling interval for the reed peat was $5 \mathrm{~cm}$. Unfortunately, the peat contained a lot of destroyed pollen and spores which hampered the study.

General trends in the pollen diagram follow the Holocene vegetational features described in Estonia (Каяк et al., 1976), particularly on Saaremaa Island (Saarse \& Königsson, 1992). Even the oldest sequences do not reflect any of the characteristic late-glacial features and due to the absence of spruce pollen, they most probably belong to the second half of the Boreal, however, the ${ }^{14} \mathrm{C}$ dates (Table) indicate the Early Atlantic age. Spruce immigrated to Saaremaa already about 8000 B. P., but its real expansion occurred not until about $4100-4000$ B. P. (Saarse \& Königsson, 1992). In our diagram a rather pronounced Picea culmination (about $5 \%$ ) was established at a depth of $2.85 \mathrm{~m}$ in the midAtlantic in the Tilia-Ulmus-Alnus-Corylus PAZ according to Saarse \& Königsson (1992), close to the maximum expansion of the broad-leaved trees.

Peat samples from two sediment depth intervals were dated by means of the radiocarbon method using the conventional liquid scintillation technique. Sample material was subjected to normal acid-alkaline-acid pretreatment to remove carbonates and humic matter having enhanced mobility. Initially, from the lower sample half of the material was used, and only the insoluble in alkaline solution fraction was measured (Tln-1875). 

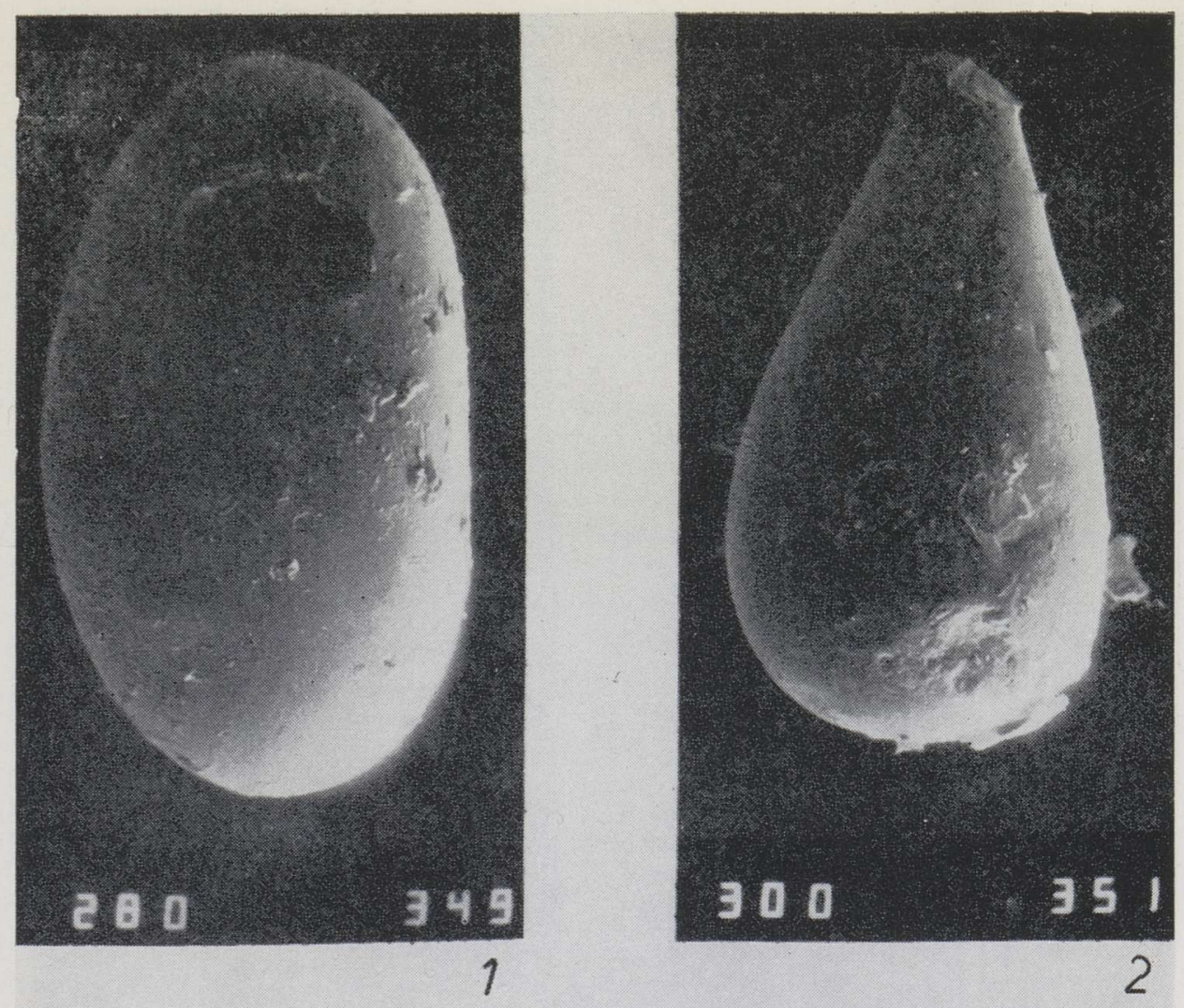

3
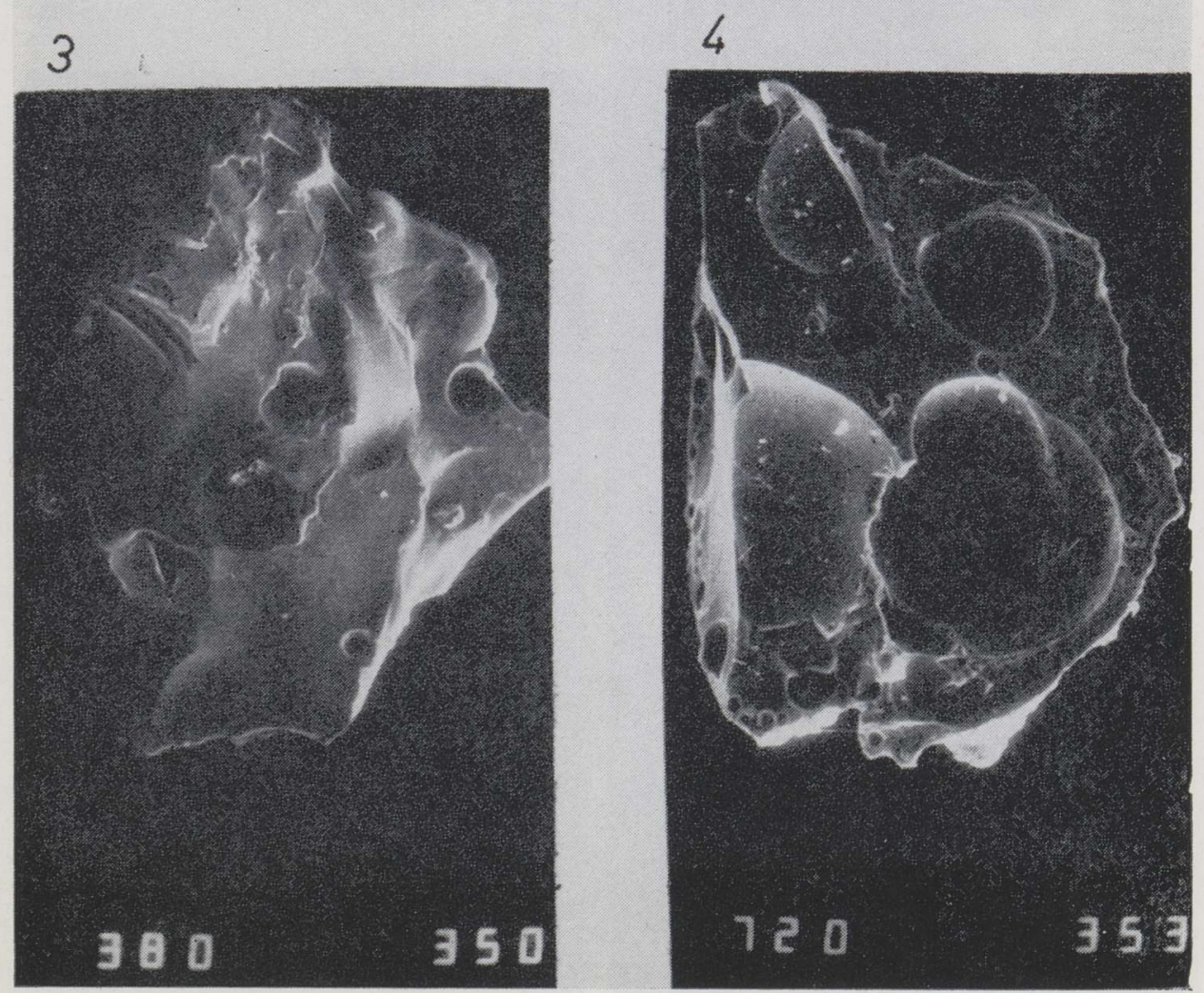

Typical spherules from the Piila mire at a depth of $3.00-3.10 \mathrm{~m}$. For the description of spherules see text, p. 180. 

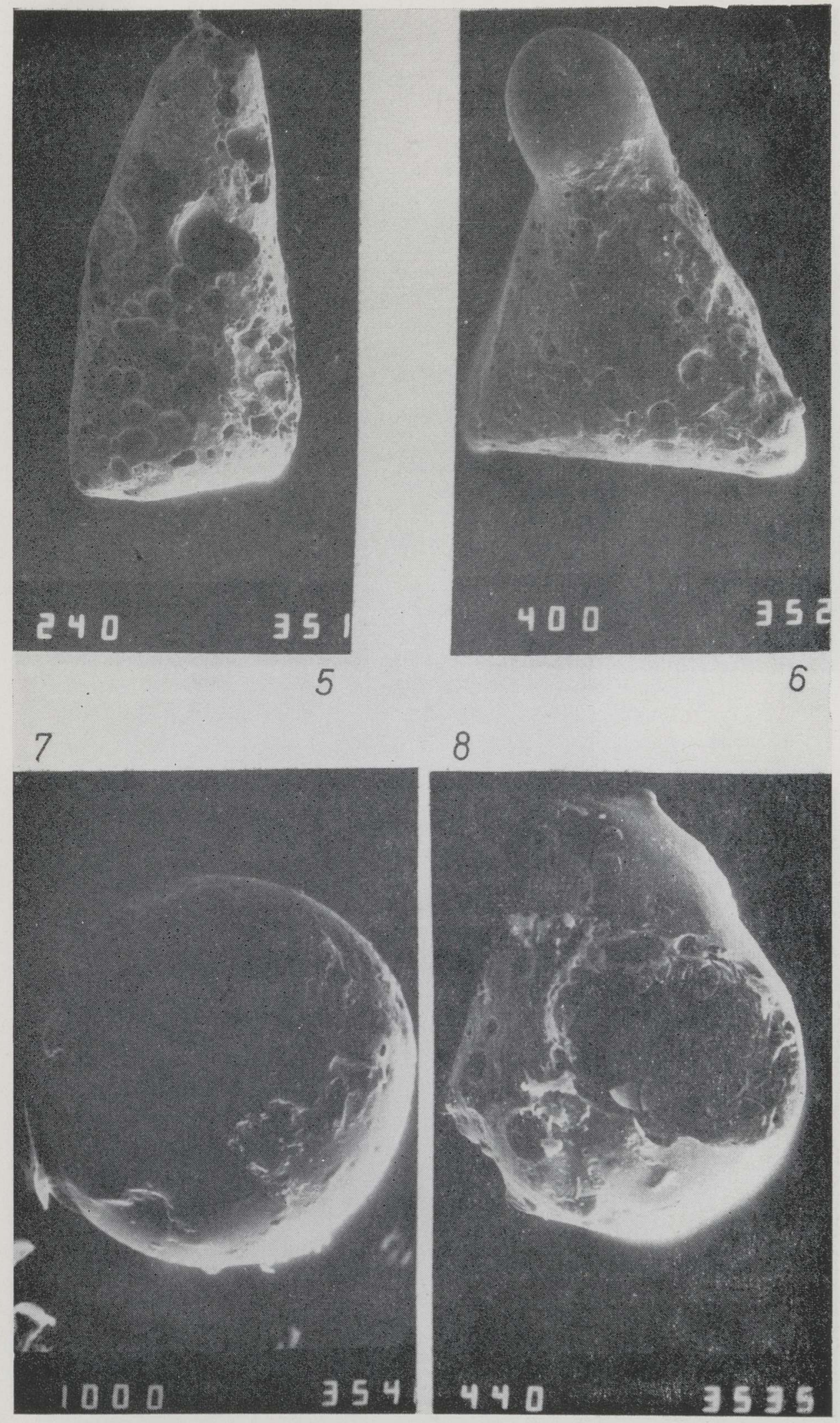


\begin{tabular}{l|l|c|c}
\hline Lab. index & Fraction analysed & Depth interval, cm & Age, yr B. P. \\
\hline Tln-1875 & Insoluble & $335-340$ & $7877 \pm 77$ \\
Tln-1881 & Insoluble & $335-340$ & $7868 \pm 135$ \\
Tln-1882 & Soluble & $335-340$ & $7992 \pm 59$ \\
Tln-1886 & Soluble & $335-340$ & $7912 \pm 67$ \\
Tln-1918 & Insoluble & $225-250$ & $2894 \pm 45$
\end{tabular}

* After the paper had been submitted several new ${ }^{14} \mathrm{C}$ dates were received. Peat from a depth of $3.05-3.10 \mathrm{~m}$ was dated $7586 \pm 67$ (Tln-1972) yr B.P. This date supports the age of the Kaali meteorite impact proposed in this paper.

In order to be sure that the impact explosion had not caused contamination of this fraction with some very old material, e. g. graphite (Olsson, 1979), the soluble fraction was also measured (Tln-1882) to check whether graphite particles had remained in the insoluble fraction separated by centrifugation. The agreement between two datings allowed to disregard the assumption of contamination both with graphite and mobile humic substances. To confirm the results, rest of sample material was analysed by the same procedure (Tln-1881, -1886). The fact that all ${ }^{14} \mathrm{C}$ ages from the lower depth interval agree within the limit of error is a clear evidence that sample organic material is formed in situ, thus, the mean value of datings gives the real age of formation for the sediment bed analysed.

The fifth dating (Tln-1918) was obtained on the integrated material from the 25-cm-thick peat layer, being, therefore, of lower significance for the purposes of stratigraphy. The datings presented in the Table are neither corrected for isotopic fractions nor dendrochronologically calibrated.

\section{CONCLUSIONS}

Both the ${ }^{14} \mathrm{C}$ dates and the Boreal transition to the Atlantic palynological spectrum in the lowermost part of the section studied suggest that the area under consideration was freed from the waters of the Baltic Sea already some 8000 years B. P. and the Kaali craters were formed probably close to 7500 B.P. This idea needs further support. With this aim a new research into spherules in the other close-lying lakes and peat bogs of Saaremaa Island and in the western part of mainland Estonia is planned for the years to come in the frames of the PACT project "Environmental History of the Baltic Region", and, hopefully, within the new IGCP project No. 384 "Extraterrestrial spherules as a new tool for global correlations". The next step in our studies will be investigation of near- and offshore sediments with an aim of finding a chronostratigraphical guide level for the Baltic region.

\section{ACKNOWLEDGEMENTS}

The research was financially supported by the PACT project "Environmental History of the Baltic Region". The authors wish to thank H. Kukk for the linguistic improvements to the text, U. Moldov and G. Baranov for the microphotos, T. Kallaste for microsond analysis, E. Tavast and J. Vassiljev for assistance with the field work, K. Kihno for the preparation of palynological samples and A. Poska for computerizing the palynological diagram. 


\section{REFERENCES}

Aaloe, A. 1958. Kaalijärve meteoriidikraatri nr. 5 uurimisest 1955. aastal. - ENSV TA Geol. Inst. Uurimused, II, 105-117.

Aaloe, A., Eelsalu, H., Liiva, A., Lõugas, V. 1975. Võimalusi Kaali kraatrite vanuse täpsustamiseks. - Eesti Loodus, 12, 706-709.

Aaloe, A., Liiva, A., Ilves, E. 1963. Kaali meteoriidikraatrite vanusest. - Eesti Loodus, $5,262-265$.

Aaloe, A., Lõugas, V., Saar, E. 1977. Asva linnuse hukkumine. - Eesti Loodus, 12, $759-762$

Kessel, H. 1981. Kui vanad on Kaali järviku põhjasetted? - Eesti Loodus, 4, 231-235.

Kraus, E., Meyer, R., Wegener, A. 1928. Untersuchungen über den Krater von Sall auf Ösel. - Kurl. Beitr. Geophys, 20, 3/4, 312-378.

Kruse, F. 1842. Necrolivonica oder Alterthümer Liv-, Ehst- und Curlands. Beilage, Dorpat.

Linstow, O. 1919. Der Krater von Sall auf Oesel. - Zentralbl. f. Min. u. Geol., 21/22, $326-329$.

Olsson, I. U. 1979. A warning against radiocarbon dating of samples containing little carbon. - Boreas, 8, 2, 203-207.

Reinwaldt, I. 1928. Bericht über geologische Untersuchungen am Kaalijärv (Krater von Sall) auf Ösel. - Publ. Geol. Inst. Univ. Tartu, 11 (also in: Loodusuurijate Seltsi Aruanded, 35, 30-70).

Reinwaldt, I. 1933. Kaali järv - the Meteorite Craters on the Island of Ösel (Estonia). Publ. Geol. Inst. Univ. Tartu, 30 (also in: Loodusuurijate Seltsi Aruanded, 39, 183-202).

Reinwald, I. 1937. Meteoorkraatrid Saaremaal. - Looduskaitse, 1, 118-131.

Reinwald, I. 1938. Der Krater von Sall (Kaali järv) - ein Meteorkrater-Feld in Estland. - Natur und Volk. Frankfurt am Main, 68, 1, 16-24.

Saarse, L., Königsson, L.-K. 1992. Holocene Environmental Changes on the Island of Saaremaa, Estonia. - In: Hackens, T., Lang, V. and Miller, U. (eds.). Estonia: Nature, Man and Cultural Heritage. PACT, 37, II. 2. 97-131.

Saarse, L., Rajamäe, R., Heinsalu, A., Vassiljev, J. 1990. Formation of the meteor crater of Lake Kaali (Island Saaremaa, Estonia). - In: Pesonen, L. J. and Niemisvaara, L. H. (eds.). Symposium on Fennoscandian impact structures. Programme and Abstracts. Espoo, 55.

Saarse, L., Rajamäe, R., Heinsalu, A., Vassiljev, J. 1991. The biostratigraphy of sediments deposited in the Lake Kaali meteorite impact structure, Saaremaa Island, Estonia. - Bull. Geol. Soc. Finland, 63, 2, 129-139.

Shimanovich, S., Kolosova, T., Raukas, A. 1995. Scanning electron microscopy of ferriferous minerals in the Quaternary deposits of the Baltic states and Belarus. Proc. Estonian Acad. Sci. Geol., 44, 2, 111-118.

Shymanovich, S., Kolosova, T., Raukas, A., Tiirmaa, R. 1993. Extraterrestrial spherules in the surroundings of Kaali meteorite craters (Saaremaa Island, Estonia). Proc. Estonian Acad. Sci. Geol., 42, 3, 127-133.

Tiirmaa, R. 1994. Kaali meteoriit. Eesti TA Geoloogia Instituut, Tallinn.

von Luce, J. W. 1827. Wahrheit und Mutmassung. Pernau.

Аалое А. 1963. Об истории изучения Каалиских метеоритных кратеров. - Тр. Ин-та геол. АН ЭССР, XI, 25-34.

Аалое А., Тийрмаа Р. 1981. Распыленное метеоритное и импактитное вещество на кратерном поле Каали. - Изв. АН ЭССР. Геол., 30, 1, 20-27.

Қаяк К., Кессел Х., Лийвранд Э., Пиррус Р., Раукас А., Сарв А. 1976. Местная рабочая стратиграфическая схема четвертичных отложений Эстонии. - In: Стратиграфия четвертичных отложений Прибалтикн. Пяргале, Вильнюс, 4-42. 


\section{KAALI METEORIIDIKRAATRITE (SAAREMAA, EESTI) VANUSEST}

Anto RAUKAS, Reet PIRRUS, Raivo RAJAMAE, Reet TIIRMAA

Eesti suurima loodusharulduse, Kaali meteoriidikraatrite vanust on hinnatud erinevate meetoditega. Enamik nüüdisuurijaid peab kraatreid 4000 aasta vanuseks. Kraatritest ca $10 \mathrm{~km}$ loodes asuva Piila soo setetest, Atlantilise vanusega turbast, leidsid autorid $3,00-3,10 \mathrm{~m}$ sügavusest arvukalt meteoriidi plahvatusele osutavaid mikrotektiite (impaktiite). Kompleksuuringute alusel saab väita, et kraatrid kujunesid ligikaudu 7500 aastat tagasi.

\section{О ВОЗРАСТЕ КААЛИСКИХ МЕТЕОРИТНЫХ КРАТЕРОВ (ОСТРОВ СААРЕМАА, ЭСТОНИЯ)}

Анто РАУКАС, Рээт ПИРРУС, Райво РАЯМЯЭ, Рээт ТИИРМАА

Возраст Каалиских метеоритных кратеров оценивался разными методами. Большинство исследователей считает, что возраст кратеров составляет около 4000 лет. В торфе расположенного в 10 км к северозападу от Каали болота Пийла на глубине $3,00-3,10$ м были найдены многочисленные микротектиты (импактиты), образовавшиеся при падении метеорита. Возраст торфа, по палинологическим и радиоуглеродным данным, атлантический. В результате комплексных исследований можно заключить, что Каалиские кратеры образовались около 7500 лет назад. 